\title{
A Research Investigation of Contextualized Grammar Instruction from the Perspective of English Language Lecturers and Students at Al-Imam Mohammad Ibn Saud Islamic University
}

\author{
Ahmad Alkhawaldeh ${ }^{1}$ \\ ${ }^{1}$ Al-Imam Mohammad Ibn Saud Islamic University, Saudi Arabia \\ Correspondence: Ahmad Alkhawaldeh, Al-Imam Mohammad Ibn Saud Islamic University, Saudi Arabia. E-mail: \\ alkhawaldeh2013@gmail.com
}

Received: June 4, $2020 \quad$ Accepted: July 11, $2020 \quad$ Online Published: July 14, 2020

doi:10.5539/ijel.v10n5p162 URL: https://doi.org/10.5539/ijel.v10n5p162

\begin{abstract}
This study investigated implicit versus explicit EFL grammar instruction by surveying the beliefs of university lecturers and students at the College of Languages and Translation at Al-Imam Mohammad Ibn Saud Islamic University/KSA regarding this significant issue. Many university lecturers who responded to the questionnaire instrument in the present study supported contextualized (implicit) grammar instruction. Likewise, open-ended questionnaire responses provided by a number of university students, at the above college, revealed that several students favored contextualized grammar instruction while explicit/conscious grammar instruction was the choice of a few of them. Meanwhile, a few students favored a combination of implicit and explicit grammar instruction. In light of the above findings, the author recommends the adoption of contextualized grammar instruction with appropriate attention be given to explicit grammar instruction.
\end{abstract}

Keywords: grammar instruction, implicit grammar learning, explicit grammar learning, communicative language teaching, English language learning

\section{Introduction}

Grammar instruction, according to Ebsworth and Schweers (1997) traditionally had a core position in foreign and second language learning. The kind of direct/ traditional grammar instruction has recently been questioned by many researchers, specialists and teachers who started to suspect the usefulness of swamping students with grammatical rules that may not aid them in communicating effectively with other language speakers using both verbal and written forms of communication. Historically, before 1967, according to Celce-Murcia (1991), teaching grammar was viewed as a habit formation and so it was central to language teaching and EFL syllabus design by adopting the audio-lingual method. Since the mid-1970s, a paradigm shift occurred which challenged this old approach to grammar instruction conceiving EFL grammar, for the first time, from a social and communicative language learning perspective. The context for the present study is the EFL grammar instruction at Al-Imam Mohammad Ibn Saud Islamic University/College of Languages and Translation (henceforth, referred to as CLT). The purpose of this study is, therefore, to examine the current trend/s in grammar pedagogy at the above college and to discuss the relevant instructional and research implications.

Obviously, there has been a controversy among various linguists and language learning researchers and specialists about whether SL/FL teachers should teach grammar rules or embed them in learning activities and situations. According to Goode (2000) and Sams (2003), at present, almost all specialists agree that grammar has not to be taught in an explicit way. In line with this direction, relevant recent theories and concepts tend to highlight pedagogical grammar, contextualized grammar and grammar in context.

Conceptually, this study is premised and rooted in Halliday's theory of systemic functional linguistics (SFL) through examining the architecture of language, the way form and meaning are combined and, most importantly, placing and envisioning language learning in a social context as illustrated above. In this vein, Halliday (1976 and 1978) drew on child language acquisition and how this is interpreted by his theory which underscores functional grammar. He also underscored the social function of language and so he emphasized that language has the role of realizing the society's structure by demonstrating the reciprocal relationship between language and society.

Further, the current study is embraced by the general framework of related second language acquisition theories 
such as Krashen's (1982) L2 acquisition theory for the related multiple pedagogical and language acquisition implications. Krashen explained that formal grammar instruction does not help the process of second language acquisition. Likewise, Prabhu (1987) argued that by using meaning-focused tasks, learners can achieve natural grammar learning. Others, such as Ellis (2002), believed that formal grammar instruction results in a delayed impact whereas the immediate impact is highly desirable and should be focused on in the SL learning process. For many teachers, teaching grammar should help learners internalize the structures taught in such a way that learners can use them in natural life communication.

Ellis (2006) believed that grammar instruction is an issue which is still unresolved by several language teachers. In the same vein, Richards and Reppen (2014) underscored two major beliefs about grammar instruction: Grammar which is perceived as knowledge and grammar which is perceived as ability. Similarly, Cullan (2012) contrasted two significant principles: One principle focuses on learning grammar through the exposure to a comprehensible input which needs to be roughly tuned to the level of the language learner. This input should, accordingly, be taught through meaning related activities and tasks. The other principle focuses on some degree of form to accelerate the acquisition process and finally to enhance levels of achievement.

Second language grammar is viewed, according to Ellis (2002), as an area of special controversy because grammar has bases manifested in the linguistic theory, in the psychology of learning as well as in language pedagogy. Krashen (1981), above cited, distinguished between conscious and unconscious language acquisition. Together with Hammond (1988), they thought that formal grammar instruction enables the achievement of declarative syntactical knowledge which does not aid using grammar for communication. Cullan (2012) focused on the communicative event and so stressed that the choice of any grammatical point is governed by the context of using language. This illustrates the importance of the communicative purpose behind grammar learning.

For several students, grammar learning may be essential to systematize speech and writing. A report appeared in the USA in 1963 harshly concluded that practiced grammar instruction, at its best status, represents a waste of the learner's time and when it is looked at from the negative side, it causes harm to the learner as expressed by Chan (2016). Due to the criticism which was directed to practiced instruction, this had negative consequences on language learning represented in the learners' low rate in global literacy performance evaluation, therefore, both the UK and the USA have recently started to give priority to grammar instruction in their respective educational plans (Chan, 2016).

Some teachers and specialists think that raising learner's consciousness pertaining to the EFL grammar can help the learner practice using it properly. For example, Schmidt (1990) clearly stressed the role of consciousness in second language learning of which explicit learning of grammar is an important component. Likewise, Rutherford and Sharwood Smith (1988) reflected on an approach by which the teacher consciously alerts learners to certain grammatical knowledge that serves their communicative task/performance.

As indicated above, research, generally, suggests that rote learning of grammatical rules does not help students communicate well. Students do not naturally transfer grammatical rules as well as patterns which are administered through worksheet drills into their own writing (Harris \& Rowan, 1989; Hillocks, 1986).

\section{Literature Review}

This part presents a review of the related literature of EFL grammar instruction. For example, Ellis (1993) examined the structural syllabus in the context of second language acquisition research. He argues that a structural syllabus cannot aid as a platform for the development of what is called as a tacit knowledge of the second language because of what he termed as the problem of learnability where learners are usually unable to learn the structural properties they are taught because the manner in which they are taught does not align with the way these learners acquire structural attributes. His perspective is that a structural syllabus has to be utilized alongside with a syllabus of meaning - based activities, which provides, according to him, learners with opportunities that facilitate second language communication.

Spada and Lightbown (2008) pointed out that there is a growing consensus that form - focused instruction assists learners in communicative as well as content - based instruction to acquire features of the target language which learners may not acquire without a special instruction provided to them. Their study compared separate/(isolated) activities instruction to communicative/(integrated) type of instruction. They concluded that these two types of instruction can be helpful, depending on the gained knowledge, the characteristics of learners as well as learning circumstances. The study revealed that both teachers and students need to give importance to the benefits of these two kinds of instruction. As far as the integrated communicative type of instruction is concerned, this was also preferred due to the focus on two factors which encompass fluency as well as automaticity. 
Schmidt (2017) described the current surprise among specialists in the ELT field with respect to teaching explicit grammar. The view, according to him, is that the world literature has not yet settled the argument about implicit versus explicit grammar instruction. Explicit grammar instruction, as he said, is associated with the traditional methods to teaching grammar. The study indicated that implicit grammar instruction is challenged for being less effective as a recent growing evidence supports this view.

Vold (2017) investigated the methodological approaches presented in grammar exercises in a set of French language textbooks written for the Scandinavian instructional envirmnoemt. Findings revealed that the developments within the research fields concerning meaningful and contextualized grammar instruction have finally started to find their way into some of the teaching courses. The study highlighted research-based considerations for grammar instruction.

Ellis and Roever (2018) reviewed research studies that measured L2 implicit and explicit grammar knowledge. Their review study started with defining implicit and explicit knowledge. According to them, implicit knowledge is investigated by using two ways: through using empirical studies and analytic investigations. This enabled the development of a taxonomy of tests designed to provide special measures of these two types of knowledge. The study concludes by proposing that there is a demand for L2 realistic knowledge assessments to complement those available for testing grammar and proposes a set of suggestions to design these tests.

Calling for a balanced approach to grammar instruction, Almazloum (2018) conducted a study about L2 learner's beliefs regarding pedagogical grammar. His study used questionnaires and interviews to gain knowledge about participants' beliefs regarding pedagogical grammar. The findings indicated that the participants constructed their own perceptions about pedagogical grammar during the adopted program. A related result was that the participants suggested that teachers should establish a balance between both explicit and implicit grammar instruction.

Recently, Almuhammadi (2020) conducted a survey study to identify the beliefs of 50 faculty members at a public university in Saudi Arabia. To achieve the purpose of the study, a questionnaire was used to collect data regarding the grammar teaching approaches subscribed to by the faculty members. Results of this study revealed that EFL teachers regard grammar as a basic framework for English language teaching. Grammar was also regarded as a crucial factor for the achievement of both accuracy and correct EFL grammar use. The author encouraged training EFL teachers to enable them to use up-to-date methods of grammar instruction to attain effective EFL teaching.

The above literature indicates that the major trend is to turn to use grammar in context and for communicative purposes. A balance between accuracy and communication fluency seems to be important. Also, paying attention to grammatical forms that may enable communicative language teaching seems to be favored by some scholars.

\section{Statement of the Problem}

The issue of using explicit grammatical rules by the FL learner or not, that is to say, to engage in the production of the language (via various language skills such as speaking and writing skills) without sticking strictly to the grammatical rules is a special instructional mode which has recently gained increased attention and momentum. In informal discussions with university students, learners raise questions such as 'Should I give so much attention to the grammar of the language while I am communicating with others in English'. Another student is just concerned about giving importance to grammatical rules in English. As an EFL professor, the researcher noticed that most grammatical problems encountered by university students seem to do with misuse of certain pronouns, misuse of appropriate verbs, misuse of the third person singular-s morpheme and misuse of the appropriate auxiliary verb. The related literature also reveals that this issue is still being unresolved despite the recent trend towards using grammar for communication and using interactive methods of teaching grammar. The present study, therefore, attempts to address this significant issue concerning the approach to teaching English grammar favored by CLT lecturers and students at Al-Imam Mohammad Ibn Saud Islamic University.

\section{Research Questions}

The current study addresses the following research questions:

1) What are the College of Languages and Translation/Al-Imam University EFL lecturers' beliefs about grammar instruction?

2) How is grammar instruction viewed by the College of languages and Translation/Al-Imam University EFL students?

3) How is grammar instruction handled in the relevant Grammar Sense 3 Textbook taught to the CLT students? 


\section{Significance of the Study}

This study gains significance because it addresses a vital instructional issue, EFL grammar instruction, which many EFL teachers and students are concerned about to attain better and effective grammar learning by university students as the case of the present study. This study may bring some evidence about grammar instruction that researchers and specialists may benefit from. University lecturers are likely to benefit from the results of this study to identify CLT lecturers' views about teaching English language grammar, a thing which may aid them in teaching EFL grammar courses. Syllabus designers may also benefit from its results to identify how the world literature, university students, university lecturers view grammar instruction and which path or route they should follow to handle grammar teaching.

\section{Limitations of the Study}

This study has the following limitations.

- The number of the participants who were randomly selected to take part in the study were from among lecturers at the College of Languages and Translation at Al-Imam University/KSA. Both lecturers and students who took part in the study were those who willingly agreed to participate and respond to the research questionnaires used to achieve the purpose of this study.

- Research instruments encompassed a close questionnaire for EFL lecturers and open-ended questionnaire for CLT students.

- The implementation of this study took place during the second semester, 2020.

\section{Methodology}

\subsection{Participants of the Study}

Sixty (60) EFL lecturers, at the above university. responded to the survey questionnaire instrument used in this study. Among the university lecturers' sample, $72 \%$ held a $\mathrm{PhD}$ in a related English language sub-discipline. 26.7\% had an MA and 1.3\% had a B.A. Regarding the field of specialization, $13.3 \%$ had a degree in linguistics, $46.7 \%$ applied linguistics, $31.7 \%$ translation and $8.3 \%$ literature. Regarding the participants' gender, $51.7 \%$ were males and $48.3 \%$ were females. As for university students, these were 26 male students who were taking Level 5 Essay Writing course and 14 male students who were taking Level 6 Essay Writing course. For each single question in the open-ended questionnaire, there is a distinct total number depending on the students who responded to it.

The researcher used quantitative as well as qualitative methods to answer the research questions. Further details are provided below.

\subsection{Questionnaire Instrument Design and Implementation}

The design of the lecturers' questionnaire underwent the following development stages:

Stage one: the researcher revised several studies and textbooks to provide a first draft of around 47 items

Stage two: The number of items was reduced to around 20 items.

Stage three: a pilot study was carried out to check if the items are appropriate in terms of content and language. After receiving reviewers' feedback, few items were modified

Stage four represents the actual implementation of the study.

The Students' open-ended questionnaire covered items related to learning English grammar implicitly in context, explicitly via conscious grammar learning or using both modes of learning.

The implementation of this study took place in the 2nd semester, 2020.

\subsection{Instrument Validity}

The two questionnaire instruments (close questionnaire for lecturers and open-ended questionnaire for the students) were forwarded to six university professors of all ranks to ensure its validity. Minor modifications were made upon the recommendations received. The final version was then prepared and used to gather relevant data.

\subsection{Reliability of the Instruments}

To ensure the reliability of the instruments, the researcher adopted a mix of quantitative and qualitative methods. A smaller number of lecturers responded again to the questionnaire items. The calculated R-value was .86 which is considered appropriate for the purpose of the study.

\subsection{Data Analysis}


The obtained data were analyzed electronically. After receiving the data from the respondents who responded to the EFL lecturers' questionnaire, the program provided the numbers and percentages for each item options. Respective statistics were tabulated in this study (as displayed in the table below) to achieve the purpose of the study. As for the students' open questionnaire, the researcher counted the number of agreement/disagreement responses and picked examples on them.

\section{Findings of the Study}

The table below presents the beliefs of the sixty (60) EFL university lecturers who were teaching English, during the implementation of the study, in the second semester, 2020, at the above University.

8.1 What Are the EFL lecturers' Beliefs About Grammar Instruction at CLT/Al-Imam University?

Table 1. University lecturers' beliefs about grammar instruction ( $\mathrm{No}=60$ respondents)

\begin{tabular}{|c|c|c|c|c|}
\hline No & Item & Agree & Neutral & Disagree \\
\hline 1 & Contextualized English grammar instruction should be based on principles of functional grammar. & $90 \%$ & 10 & 0 \\
\hline 2 & $\begin{array}{l}\text { In teaching contextualized English grammar, I encourage students to read a passage to locate the } \\
\text { target grammatical form depending on the context. }\end{array}$ & $81.7 \%$ & 10 & $8.3 \%$ \\
\hline 3 & I encourage learners to engage in critical thinking activities to understand grammatical forms. & $81.6 \%$ & 11.3 & $7.1 \%$ \\
\hline 4 & I encourage teaching English grammar as isolated grammatical rules. & $23.3 \%$ & 6.7 & $70 \%$ \\
\hline 5 & I encourage using independent learning activities to understand grammatical forms. & $81.7 \%$ & 11.7 & 6.6 \\
\hline 6 & I prefer to teach English grammar through group work activities. & $71.7 \%$ & 20 & $8.3 \%$ \\
\hline 7 & I urge students to analyze actions in dialogues that embody grammatical forms. & $80 \%$ & 8.3 & $11.7 \%$ \\
\hline 8 & I encourage explicit English grammar instruction. & $53.3 \%$ & 20 & $26.7 \%$ \\
\hline 9 & $\begin{array}{l}\text { I urge students to engage in writing tasks which are based on a reading passage to recycle learning } \\
\text { grammatical forms. }\end{array}$ & $91.7 \%$ & 8.3 & 0 \\
\hline 10 & I encourage self-correction activities to correct grammatical mistakes. & $83.4 \%$ & 8.3 & $8.3 \%$ \\
\hline 11 & $\begin{array}{l}\text { Teaching grammar in context requires making connections between grammatical patterns and the } \\
\text { meanings of a certain text. }\end{array}$ & $88.3 \%$ & 8.3 & $3.4 \%$ \\
\hline 12 & Grammar teaching should highlight form together with meaning as well as use. & $88.4 \%$ & 0 & $11.6 \%$ \\
\hline 13 & Contextualized grammar instruction should be based on the learner's cognitive strategies. & $70 \%$ & 26.7 & $3.3 \%$ \\
\hline 14 & Contextualized grammar instruction should be based on the learner's communication skills. & $65 \%$ & 21.7 & $13.3 \%$ \\
\hline 15 & I believe that grammar should be taught for the test. & $11.6 \%$ & 11.7 & $76.7 \%$ \\
\hline 16 & $\begin{array}{l}\text { I encourage students to read a text, identify its grammatical forms and compare and contrast these } \\
\text { forms to understand them. }\end{array}$ & $88.3 \%$ & 10 & $1.7 \%$ \\
\hline 17 & $\begin{array}{l}\text { I encourage completion of dialogues with appropriate grammatical forms then acting out these } \\
\text { dialogues to understand the target forms. }\end{array}$ & $71.8 \%$ & 15 & $13.2 \%$ \\
\hline 18 & $\begin{array}{l}\text { I encourage students to listen to a conversation then distinguish between correct and incorrect } \\
\text { grammatical forms. }\end{array}$ & $78.3 \%$ & 10 & $11.7 \%$ \\
\hline 19 & $\begin{array}{l}\text { I like to teach grammar first in context then teach it explicitly to ensure the accuracy of using } \\
\text { grammatical rules. }\end{array}$ & $76.7 \%$ & 8.3 & $15 \%$ \\
\hline
\end{tabular}

Several significant themes emerge from the above presentation among which are the following:

- University lecturers' responses reveal that many EFL lecturers at the above college prefer to teach grammar in context.

- University lecturers tend to encourage an integrative approach to teaching EFL grammar where grammatical input needs to be recycled via several language learning activities.

8.2 What Are the Suggestions and Remarks Presented by the CLT Lecturers Regarding EFL Grammar Instruction?

A number of suggestions and remarks the respondents provided are displayed in the table below. 
Table 2. Suggestions and remarks provided by Al-Imam University CLT lecturers who responded to the questionnaire instrument

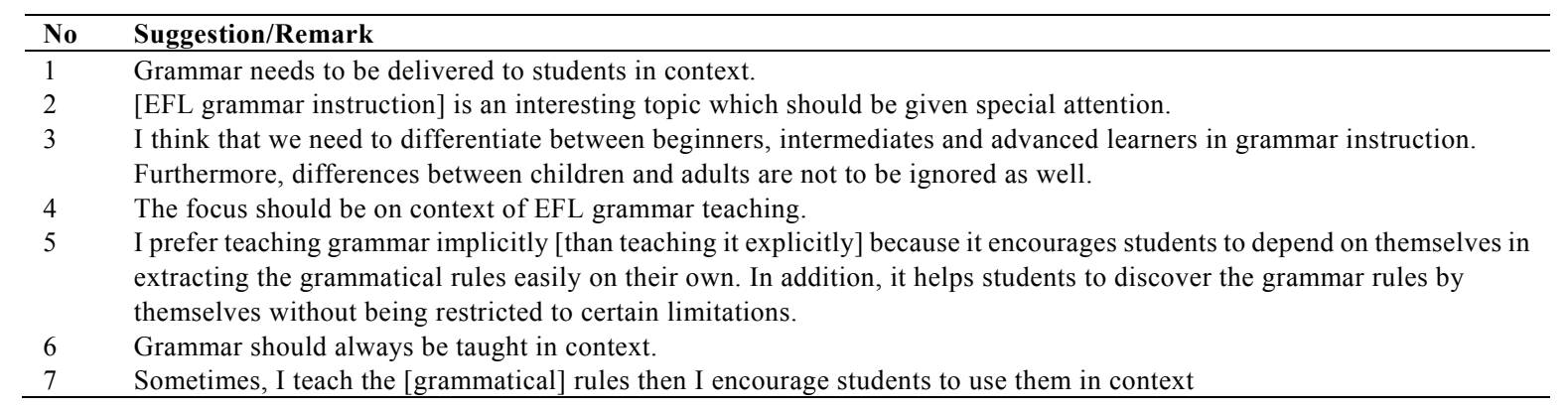

8.3 What Are the Beliefs of a Number of College of Languages and Translation Students About Grammar Instruction?

The related results which emerged from the analysis of the data obtained by the open-ended questionnaire are presented in the table below. As displayed in the table, there is a distinct total number of respondents for each questionnaire item. Worth pointing out that the total number of the students who voluntarily responded to each item in the open-ended questionnaire varies depending on the students who responded to it from among the total number of forty students as mentioned above. 
Table 3. University students' views about EFL grammar instruction

\begin{tabular}{|c|c|c|c|c|c|c|c|}
\hline & Question & $\begin{array}{l}\text { Number of respondents } \\
\text { for each question }\end{array}$ & Agree & $\%$ & Disagree & $\%$ & Example \\
\hline 1 & $\begin{array}{l}\text { Do you like to } \\
\text { learn grammatical } \\
\text { rules by explicitly } \\
\text { explaining them to } \\
\text { you? }\end{array}$ & 16 & 6 & $37.5 \%$ & 10 & $62.5 \%$ & $\begin{array}{l}\text { \# I do not like it [explicit learning of grammar rules] } \\
\text { because this is an old way. } \\
\text { \# Learning grammar by rules could be helpful, but I } \\
\text { do not like it. } \\
\text { \# Yes, because it [explicit learning of grammar } \\
\text { rules] helps me to know rules grammatically and } \\
\text { then use them in sentences }\end{array}$ \\
\hline 2 & $\begin{array}{l}\text { Do you like to } \\
\text { learn grammar } \\
\text { rules by learning } \\
\text { them in real } \\
\text { situations with } \\
\text { various examples } \\
\text { then you derive the } \\
\text { rules from the } \\
\text { given examples? }\end{array}$ & 20 & 16 & $80 \%$ & 4 & $20 \%$ & $\begin{array}{l}\text { \# I like learning grammatical rules by examples } \\
\text { then finding out the rules and so master the skill. } \\
\text { \# Knowing the grammar in situations makes it much } \\
\text { easier. However, learning the form of the } \\
\text { grammatical rules makes me much more sure of the } \\
\text { grammar. } \\
\text { \# Sometimes, I like learning English in situations } \\
\text { \# I prefer to learn the grammatical rules first } \\
\text { without interruption then applying the rules in a life } \\
\text { situation or school activities. }\end{array}$ \\
\hline 4 & $\begin{array}{l}\text { When you engage } \\
\text { in a speaking } \\
\text { activity, do you } \\
\text { consciously } \\
\text { monitor your } \\
\text { grammatical } \\
\text { accuracy? }\end{array}$ & 20 & 14 & $70 \%$ & 6 & $30 \%$ & $\begin{array}{l}\text { \# Yes, I always check my speaking performance to } \\
\text { follow grammatical rules } \\
\text { \# Yes, depending on the addressee. } \\
\text { \# It depends sometimes on who I am talking to. } \\
\text { When I am speaking to my friend, I do not check my } \\
\text { grammatical accuracy, but when I go to university, I } \\
\text { mostly check my grammatical accuracy. } \\
\text { \# Actually, when someone speaks, I listen to him to } \\
\text { examine how he uses the grammatical rules. It helps } \\
\text { me understand more and learn how to use them. } \\
\text { \# To be honest, I do not check, in times of study I } \\
\text { always go and check my accuracy. } \\
\text { \# Yes, I do check my grammar accuracy and when I } \\
\text { make a grammatical mistake. I immediately try to } \\
\text { pronounce again the word or a sentence correctly, } \\
\text { \# Because I am a slow speaking person, it matters } \\
\text { that the receiver may not understand my words at } \\
\text { any state whether in the tense or signs. } \\
\text { \# We can say yes and no. Yes, we need to speak } \\
\text { grammatically while we are at university or school. } \\
\text { Any way, we do not need to speak with correct } \\
\text { grammar at home because it is not an academic } \\
\text { place. }\end{array}$ \\
\hline 5 & $\begin{array}{l}\text { Do you prefer to } \\
\text { learn grammar in } \\
\text { context? }\end{array}$ & 20 & 15 & $75 \%$ & 5 & $25 \%$ & \\
\hline
\end{tabular}

In response to a question directed to university students about how much they tend to be accurate and avoid committing any grammatical mistakes in essay writing, one student said: 'I just focus on writing and put my ideas into paper. I then check grammatical accuracy.' Regarding grammatical accuracy handled in the essay writing task, several students, in an essay writing task developed during the second semester, 2020, committed some grammatical mistakes depending on the level of the student.

Also, in response to a question whether students like to learn grammatical rules through learning situations, out of 18 university students, $14(77.7 \%)$ wanted to learn grammar in situations then derive the grammatical rules, highlighting the use of an inductive mode of learning. On the other hand, four (4) students (22.2\%) disagreed on learning grammatical rules through learning situations, favoring the use of an explicit way of learning the EFL grammar. This may indicate that despite a general trend towards contextualized implicit grammar learning prevails among university students, still explicit learning of the English grammar may need to be considered in 
teaching the respective grammar courses. Several students showed tendency toward checking their grammatical accuracy mainly in formal learning situations.

\subsection{How Is Grammar Instruction Handled by Grammar Sense 3 Textbook Which Is Taught to the Above CLT Students?}

The above college students' beliefs may be influenced by the textbooks they study in their B.A. program. Therefore, to support the above results and help draw a picture of the EFL grammar instruction context, the researcher examined (Grammar Sense 3) textbook authored by Susan Kesner Blland (2012) which was taught to the CLT students as part of their B.A study. The table below reveals some related content from Chapter One (The Present: pp. 3-27) in the above Grammar Sense 3 textbook.

Table 4. Relevant activities from Grammar Sense 3 textbook

\begin{tabular}{lll}
\hline No & Instance & Relevant Activity/Skill \\
\hline 1 & A: Grammar as & - Discussing daily habits that require the use of the target structure such as simple present tense \\
manifested in & - Reading a passage to locate the target grammar point \\
discourse & - Giving a grammatical form in various learning activities to strengthen processing the selected grammar \\
& points \\
B: Form: Using & - Identifying a certain (underlined) form \\
critical thinking & - Describing the differences between negative forms used in the simple present tense and those used in the \\
when handling & present continuous tense \\
grammatical & - Changing a group of certain sentences \\
forms & - Listening to focus on form activities \\
& - Working on certain verb forms \\
& - Working on selected statements \\
& - Engaging in an informal speaking activity to strengthen the use of the target grammatical forms
\end{tabular}

\section{Discussion}

Through surveying the related literature in this study, it was noticed that many scholars in the field of language teaching highlighted contextualized grammar learning and teaching. This is consistent with a world-wide trend towards making grammar instruction an implicit venture. According to Goode (2000) and Sams (2003), specialists agree that grammar should be taught in context.

Though contextualized grammar instruction should be given primacy, explicit grammar instruction does not seem to be totally overlooked as indicated by some students' responses. Grammar instruction should be embedded in various social learning activities. The majority of university lecturers who responded to the questionnaire instrument, in the present study, supported contextualized grammar instruction. The majority also encouraged students to read a passage to locate the target grammatical form depending on the context valuing, at the same time, the integration of grammar into language learning skills and activities.

In response to a question about whether the EFL lecturers at the above college subscribe to a teaching methodology that endorses integrating grammatical rules into the various language learning skills and activities and not teaching them void of context, a high percentage $(70 \%)$ of these lecturers disagreed on teaching isolated grammatical rules. Also, with regard to linking contextualized grammar instruction, a thing which reveals the lecturers' awareness of the importance of enabling students to communicate adequately using English by teaching grammar in context, 65\% EFL lecturers supported this trend in teaching grammar to enhance communication.

Further, a related view was to teach grammar first in context then consciously alert and draw students' attention to its grammatical form. This was the essence of a questionnaire item about teaching grammar first in context then teaching it explicitly to ensure the accuracy of using grammatical rules. This received the response of $76.7 \%$ of the university lecturers in this study, an instructional mode which may match with what some students went far as to suggest a combination of explicit and implicit grammar instruction in teaching grammar courses.

In response to the item whether the lecturers encourage students to read a passage to locate the target grammatical form depending on the context, this received the agreement of $81.7 \%$ of the university lecturers who participated in this study. This signifies and reaffirms the prevailing trend among the majority of the lecturers about the value of teaching grammar in context. 
Anyway, an integrative approach to teaching grammar was supported by the majority of the lecturers. For example, in response to the item 'I encourage students to read a text, identify its grammatical forms and compare and contrast these forms to understand them,' $88.3 \%$ of the lecturers supported this trend which reveals the interplay between grammar instruction and other language learning skills and activities.

The study brought evidence that several students check their understanding of grammar while speaking and try to correct themselves to attain a better proficiency of the English language. Students check grammar, according to the speaking context, that is, when in an academic institution, they tend to be more conscious and careful that their use of the English language is grammatically accurate. Conversely, when they are in informal settings, they tend to be less conscious as expressed by individual students in this study. Spada and Lightbown (2008) meta-analyzed a set of studies and mentioned that there is a growing agreement among those interested in language teaching that form - focused instruction enables learners in an instruction based on communicative or content - based approach to acquire features related to the target language which these learners may not get without a special instruction offered to them. Likewise, Almazloum (2018) recommended that teachers should make a balance between both explicit and implicit grammar instruction. Karsou (2005) reflected on the communicative language syllabus of which grammar teaching is an essential component.

It seems that, at present, syllabus designers tend to adopt an approach of contextualized grammar instruction while, at the same time, give scant attention to explicit grammar learning. This is also supported by the views of many instructors and students who participated in this study. An examination of a chapter from the above Grammar Sense 3 textbook revealed that major emphasis is placed on grammar in context through various learning activities, but still explicit grammar instruction is not ignored where it receives scant attention.

\section{Conclusion and Recommendations}

1)Though contextualized grammar instruction appears to be given primacy, explicit grammar instruction does not seem to be totally ignored.

2) Grammar instruction should be embedded in various social learning activities.

2) The majority of university lecturers supported contextualized grammar instruction.

3) There is a clear evidence that several students check their grammar while speaking and so try to correct their language use to attain a better production of the English language.

4) Several students seem to be more conscious and careful that their use of the English language is grammatically accurate. On the other hand, when they are in informal settings, they tend to be less grammatically conscious.

5) Further studies are needed to examine grammar instruction in various instructional settings and levels.

\section{Recommendations}

1) The researcher suggests that EFL specialists adopt a combination of implicit and explicit grammar instruction though the former should receive a core attention in this suggested approach.

2) Further empirical studies are needed to measure how much implicit and explicit grammar instruction should be provided to the students.

3) EFL grammatical input needs to be recycled via several learning activities so that an appropriate grammatical competence may developed to enable the EFL learner to attain further effective communication.

4) EFL syllabus designers should consider the proportional distribution and attention to the grammatical input when teaching English language grammar. Grammar instruction should be contextualized with appropriate attention be given to conscious grammar learning depending on the learning activity and the learner's level and proficiency.

\section{Acknowledgements}

The author acknowledges the support from the Deanship of Scientific Research at Al-Imam Mohammad Ibn Saud Islamic University (Research project No. 18-11-07-004). He also thanks the lecturers who participated in the study at the College of Languages and Translation at the above university and those who facilitated its implementation.

\section{References}

Almazloum, M. (2018). Pedagogical Grammar: Learners' beliefs Do Matter. International Journal of Language and Linguistics, 5(3), 40-46. https://doi.org/10.30845/ijll.v5n3p4 
Almuhammadi, A. (2020). Teaching Grammar: Professional Needs of Saudi EFL Instructors. International Journal of English Linguistics, 10(3), 14-20. https://doi.org/10.5539/ijel.v10n3p14

Bland, S. (2012). Grammar Sense 3. Oxford: Oxford university press.

Celce-Murcia, M. (1991). Grammar Pedagogy in Second and Foreign Language Teaching. TESOL Quarterly, 25(3), 459-480. https://doi.org/10.2307/3586980

Chan, P. (2016). Why Don't U.S. Schools Teach Grammar? Retrieved on January 28, 2020, from https://ttlearning.com/blog/why-dont-us-schools-teach-grammar/

Cullen, R. (2012). Grammar instruction. In A. Burns \& J. C. Richards (Eds.), The Cambridge Guide to Pedagogy and Practice in Second Language Teaching (pp. 258-266). Cambridge: Cambridge University Press.

Ebsworth, M., \& Schweers, W. (1997). What researchers say and practitioners do: Perspectives on conscious grammar instruction in the ESL classroom. Applied Language Learning, 8(2), 237-260.

Ellis, R. (1993). The Structural Syllabus and Second Language Acquisition. TESOL Quarterly, 27(1), 91-113. https://doi.org/10.2307/3586953

Ellis, R. (2002). Grammar Teaching-Practice or Consciousness-Raising? In J. C. Richard \& W. A. Renandya (Eds.), Methodology in Language Teaching: An Anthology of Current Practice (p. 168). Cambridge: Cambridge University Press. https://doi.org/10.1017/CBO9780511667190.023

Ellis, R. (2006). Current issues in the teaching of grammar. An SLA Perspective. TESOL Quarterly, 40(1), 83107. https://doi.org/10.2307/40264315

Ellis, R., \& Roever, C. (2018). The measurement of implicit and explicit knowledge. The Language Learning Journal. https://doi.org/10.1080/09571736.2018.1504229

Goode, D. (2000). Creating a context for developmental English. Teaching English in the Two-Year College, 27(3), 270-277.

Halliday, M. A. K. (1976). Functions and universals. In G. Kress (Ed.), Halliday: System and Function in Language (pp. 26-35). London: Oxford University Press.

Halliday, M. A. K. (1978). An interpretation of the functional relationship between language and social structure. In Q. Uta (Ed.), Sprachstruktur - Sozialstruktur: Zure Linguistichen Theorienbildung (Vol. 10 of The Collected Works, pp. 3-42).

Hammond, R. (1988). Accuracy versus communicative competency: The acquisition of grammar in the second language classroom. Hispania, 71(2), 408-417. https://doi.org/10.2307/343089

Harris, M., \& Rowan, K. E. (1989). Explaining grammatical concepts. Journal of Basic Writing, 8(2), 21-41. Retrieved from https://www.jstor.org/stable/43443524

Hillocks, G. (1986). Research on written composition: New directions for teaching. Urbana, IL: ERIC Clearinghouse on Reading and Communication Skills and the National Conference on Research in English.

Karsou, M. (2005). An evaluation of action pack textbooks as perceived by Jordanian English language supervisors, teachers and students. Unpublished Master Thesis, The University of Jordan.

Krashen, S. (1981). Second language acquisition and second language learning. Oxford: Pergamon.

Krashen, S. (1982). Principles and Practice in Second Language Acquisition. Oxford: Pergamon Press.

Peterson, J. (1997). Grammar Consciousness Raising Tasks. Unpublished MA Assignment, University of Reading, England.

Prabhu, N. S. (1987). Second language pedagogy. Oxford: Oxford University Press. https://doi.org/10.2307/3587293

Richards, J., \& Reppen, R. (2014). Towards a Pedagogy of Grammar Instruction. RELC Journal, 45(1), 5-25. https://doi.org/10.1177/0033688214522622

Ruthrford, W., \& Sharwood Smith, M. (Eds.) (1988). Grammar and second language teaching (pp. 107-116). New York: Newbury House.

Sams, L. (2003). How to teach grammar, analytical thinking, and writing: a method that works. English Journal, 92(3), 57-65. https://doi.org/10.2307/822261

Schmidt, A. (2017). What is More Effective: Explicit or Implicit Grammar Instruction? Retrieved March 22, 
2020, from https://www.eltresearchbites.com/201705-what-is-more-effective-explicit-or-implicit-grammar-instruction/

Schmidt, R. (1990). The role of consciousness in second language learning. Applied Linguistics, 11(2), 129-158. https://doi.org/10.1093/applin/11.2.129

Spada, N., \& Lightbrown, B. (2008). Form-focused instruction: isolated or integrated? TESOL Quarterly, 42(2), 181-207. https://doi.org/10.1002/j.1545-7249.2008.tb00115.x

Vold, E. T. (2017). Meaningful and contextualized grammar instruction: what can foreign language textbooks offer? The Language Learning Journal, 48, 133-147. https://doi.org/10.1080/09571736.2017.1357745

\section{Copyrights}

Copyright for this article is retained by the author, with first publication rights granted to the journal.

This is an open-access article distributed under the terms and conditions of the Creative Commons Attribution license (http://creativecommons.org/licenses/by/4.0/). 